\title{
THE COMPOSITION, PHYSICAL PROPERTIES AND OCCURRENCE OF EUCRYPTITE FROM THE HAAPALUOMA PEGMATITE, FINLAND
}

\author{
SEPPO I. LAHTI, PEKKA KALLIO and O. von KNORRING
}

\begin{abstract}
LAHTI, SEPPO I.; KALLIO, PEKKA and von KNORRING, O.: The composition, physical properties and occurrence of eucryptite from the Haapaluoma pegmatite, Finland. Bull. Geol. Soc. Finland 54, 1-2, $5-13$.
\end{abstract}

Eucryptite has been found as nodules and aggregates up to ten centimetres in diameter from the Haapaluoma lithium pegmatite in Peräseinäjoki, western Finland. The mineral occurs as a rare accessory in postmagmatic fracture fillings and replacement bodies associated with quartz, cleavelandite and lithium silicates (elbaite, lepidolite and spodumene). Chemical analysis shows: $\mathrm{SiO}_{2} 51.74 \%, \mathrm{Al}_{2} \mathrm{O}_{3} 36.76 \%$, $\mathrm{Li}_{2} \mathrm{O} 9.70 \%, \mathrm{Fe}_{2} \mathrm{O}_{3 \text { tot }} 0.99 \%$, CaO $0.30 \%, \mathrm{Na}_{2} \mathrm{O} 0.26 \%, \mathrm{~K}_{2} \mathrm{O} 0.16 \%$, $\mathrm{H}_{2} \mathrm{O}+1.02 \%$. Electron microprobe analysis, however, indicates smaller amounts of $\mathrm{SiO}_{2}(47.5 \%)$ and higher amounts of $\mathrm{Al}_{2} \mathrm{O}_{3}(39.4 \%)$, corresponding to the nearly theoretical formula $\left(\mathrm{LiAlSiO}_{4}\right)$ of the mineral. Spectrochemically analysed minor elements are given. On the basis of X-ray studies the unit cell data are: $a_{\text {hex }}=13.473 \AA, c_{\text {hex }}=$ $9.000 \AA, V_{\text {hex }}=1414.87 \AA^{3}$, space group $\mathrm{R} \overline{3}$. The indexed X-ray powder pattern is given. The specific gravity is 2.657 and the calculated density $2.663 \mathrm{~g} / \mathrm{cm}^{3}$.

The mineral is grey or brown when altered. Some of the eucryptite specimens are polysynthetically twinned. The optical properties are $\varepsilon=1.585, \omega=1.572$. Unlike eucryptite specimens from other localities, the mineral does not fluoresce in short- or long-wave UV light. Eucryptite is rare, and this is the first record of the mineral in Finland.

Seppo I. Lahti, Geological Survey of Finland, Kivimiehentie 1, SF02150 Espoo 15, Finland.

Pekka Kallio, Geological Survey of Finland, PL 237, SF-70101 Kuopio 10, Finland.

O. von Knorring, Geological Survey, P.O. Box 2168, Windhoek 9000 , South West Africa/Namibia.

\section{Introduction}

Low-temperature $\alpha$-eucryptite was found as a rare accessory mineral in the Haapaluoma pegmatite in Peräseinäjoki, western Finland. The mineral is rare, usually only oc- curring in small amounts in lithium pegmatites. Althought eucryptite has not been found before in Finland, it may occur in association with spodumene and petalite in other lithium pegmatites as well. The mineral bears such a strong resemblance to quartz 
that it is often impossible to distinguish these minerals without X-ray powder diffraction patterns. The minerals are similar in colour and hardness, and they are both optically uniaxial and positive.

The Haapaluoma pegmatite, which was found in 1955, has been operated since 1961 by the companies Suomen Mineraali - Paraisten Kalkki Oy and Oy Lohja Ab. The main mineral quarried is potassium feldspar. The mineralogy and petrology of the pegmatite has been described in detail by Haapala (1966), and the surrounding area has been mapped by Tyrväinen (1970) and first of the authors (unpublished map sheet 2221 Jalasjärvi).

The pegmatite consists of two adjacent parallel dykes trending east-west and sharply intersecting the granodioritic country rock. The pegmatite is distinctly zoned and mineralogically complex. Haapala (1966) and Haapala, Siivola and Löfgren (1967) have recorded about 26 minerals from the eastern, main quarry. Some of the minerals are very rare and new to Finland. The western dyke, which contains only schorl, garnet, apatite, löllingite, pyrite, lepidolite and zoned pinkgreen tourmaline as major accessory minerals is mineralogically less interesting.
The first specimen of eucryptite was identified by one of us (S.I.L.) in a sample supplied by Mr. Heikki Koivisto, a keen mineral collector. First of the authors found later several eucryptite samples from the eastern main quarry and Mr. Pekka Paananen provided a further specimen for the present study. Concerning the authors, S. I. Lahti is responsible for the optical and single crystal X-ray studies. P. Kallio carried out the diffractometer studies and $\mathrm{O}$. von Knorring the wet chemical analyses of the mineral.

\section{Occurrence}

The Haapaluoma eucryptite occurs in the form of rounded or irregular nodules or aggregates $2-10 \mathrm{~cm}$ in diameter in cleavelandite-quartz-lepidolite-tourmaline rock or as anhedral crystals in quartz aggregates associated with the above-mentioned minerals (Fig. 1). The eucryptite-bearing specimens also include small amounts of white microcline, spodumene, cookeite, beryl, cassiterite and fluorapatite. Clay minerals (kaolinite and montmorillonite) are found as alteration products of spodumene and feldspars. The eucryptite nodules are fresh or partially al-

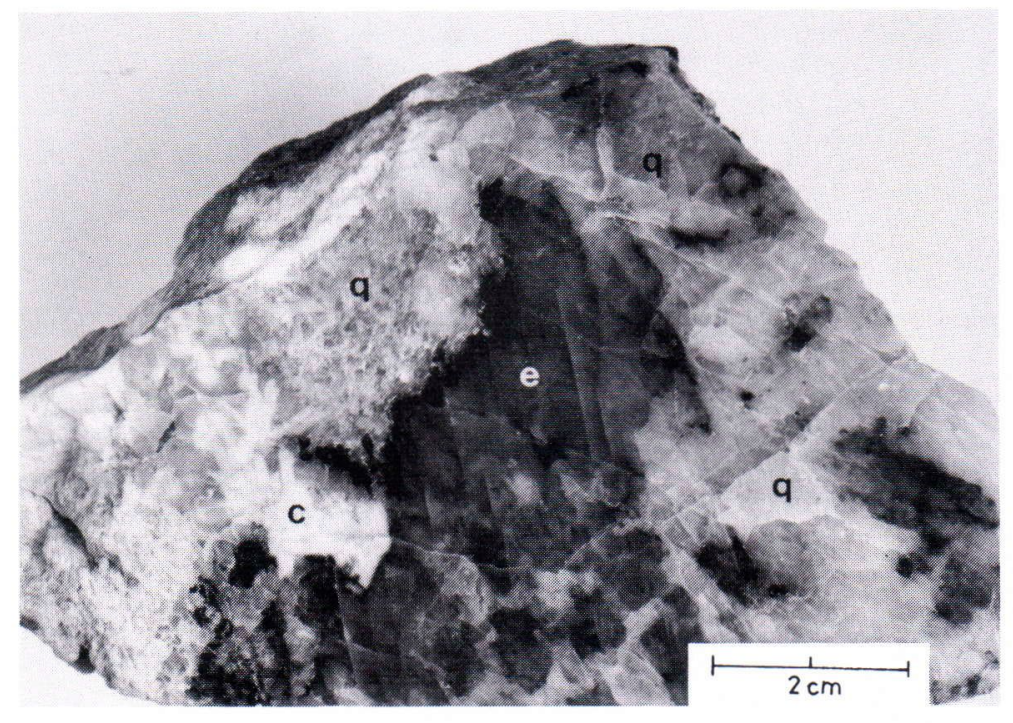

Fig. 1. Eucryptite (e, dark grey) in quartz (q, light grey) with some cleavelandite (c, white) plates. Note the subvertical lineations in eucryptite due to twinning. Polished sample. 
tered into a brown resinous, optically isotropic substance that gives some weak X-ray powder reflections of cookeite. This brown marginal alteration product is indicative of the eucryptite nodules and. helps to distinguish the mineral from quartz (Fig. 2).

Anhedral or subhedral quartz and red tourmaline crystals are common inclusions in the eucryptite. In some samples, however, quartz seems to replace eucryptite (Fig. 3). Cookeite occurs as a pink mass around the nodules and as thin veins within the eucryptite. The associated tourmaline (elbaite) is zoned, having a green core and a pink rim. Lepidolite is found as small purplish flakes some $\mathrm{mm}$ in diameter and the associated spodumene is grey in colour and may be partly or completely altered. The spodumene pseudomorphs are brown and consist of kaolinite, montmorillonite and cookeite.

\section{Physical properties}

The Haapaluoma eucryptite is usually grey or, when altered, brown. The fresh mineral resembles quartz, which, in association with eucryptite, is grey, light brown or white. The only distinguishing feature is that eucryptite is often marginally altered into a light or dark-brown alteration product (Fig. 1 and 2).

The refractive indices given in Table 1 were determined using immersion liquids and sodium light. The optical properties agree well with those reported in the litterature. The specific gravity of the mineral measured by suspension in heavy liquids and Westphal balance is 2.657 , which is somewhat lower than the calculated density of 2.663. This difference is probably due to numerous inclusions and fractures observed in the mineral.

All the natural and synthetic eucryptite specimens reported in the literature fluoresce red or carmine in short-wave UV light.
The Haapaluoma eucryptite which does not fluoresce, is an exception. Even so, when the light source is close to the sample, some parts of the specimen may fluoresce dark red.

\section{Twinning}

Thin section studies showed that some of the eucryptite samples are polysynthetically twinned. The samples consist of alternating thin and broad twin lamellae (Fig. 2), and it is sometimes possible to recognise the twinning with the naked eye (Fig. 1). Electron microprobe analysis showed no deviation in chemical composition between adjacent lamellae. According to U-stage determinations, the angle between the optic axes of two adjacent crystals is about $74^{\circ}$ and the angle between the composition plane of the crystals and the optic axis $37^{\circ}$. Because eucryptite is a trigonal mineral, the crystallographic $\varrho$ angle of this plane is $53^{\circ}\left(90^{\circ}-37^{\circ}\right)$. The indexing of eucryptite on a stereographic net and calculating the $\varrho$ values on the basis of the axial ratio of the mineral ( $c: a=0.668$, calculated from the unit cell dimensions) showed that the twin plane could be one of the following:

(11) 1$)$, with $\Phi=0^{\circ}, \varrho=53.2^{\circ}$

(2111), with $\Phi=60^{\circ}, \quad \varrho=53.2^{\circ}$

(5053), with $\Phi=30^{\circ}, \varrho=52.1^{\circ}$

(0553), with $\Phi=30^{\circ}, \quad \varrho=52.1^{\circ}$

Table 1. The physical properties of the Haapaluoma eucryptite.

\begin{tabular}{ll} 
The unit cell: & The optical properties: \\
Trigonal & $\omega=1.585$ \\
Space group $\mathrm{R} \overline{3}$ & $\varepsilon=1.572$ \\
$\mathrm{a}_{\text {hex. }}=13.473 \AA \pm 0.005 \AA$ & $\omega-\varepsilon=0.013$ \\
$\mathrm{c}_{\text {hex. }}=9.000 \AA \pm 0.005 \AA$ & \\
$\mathrm{V}_{\text {hex. }}=1414.87 \AA^{3}$ & \\
$\mathrm{G}=2.657$ & \\
$\mathrm{D}=2.663 \mathrm{~g} / \mathrm{cm}^{3}$ & \\
\hline
\end{tabular}




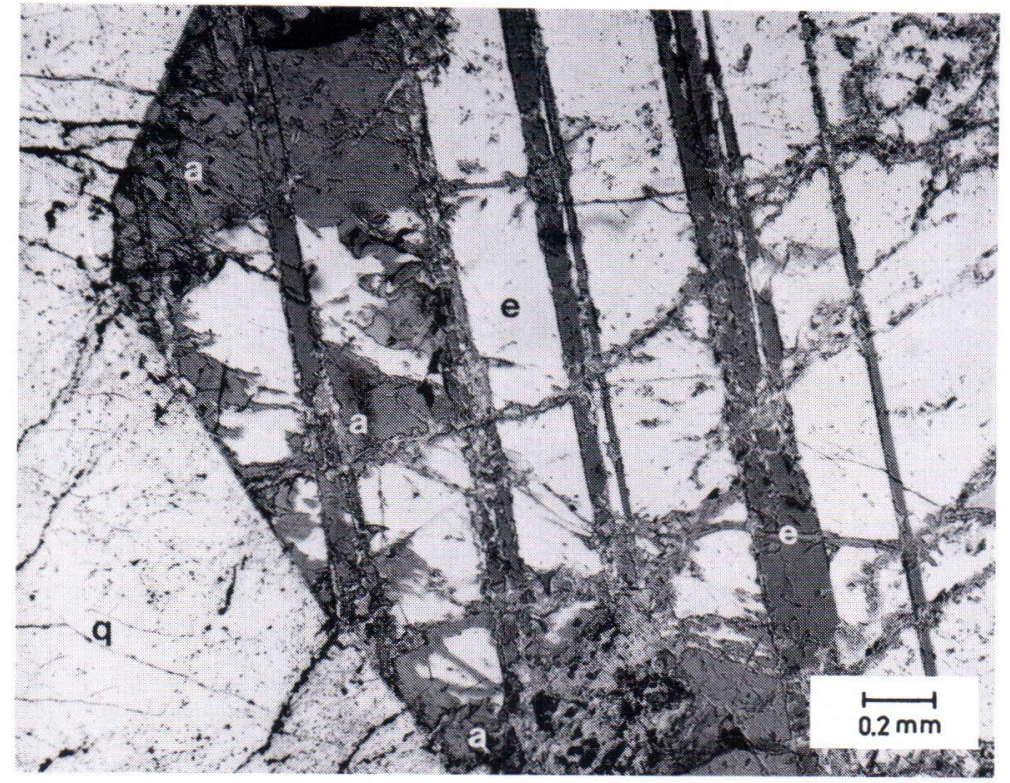

Fig. 2. Polysynthetically twinned eucryptite (e, white and dark grey lamellae) nodule against quartz (q, left part). The margin of the eucryptite nodule consist of an isotropic alteration product (a, dark grey) that replaces fresh eucryptite. Photomicrograph, crossed nicols.
Because the crystallographic $\Phi$ angle is unknown, it is not possible to determine the exact index of the twin plane. In addition, some thin sections showed twin lamellae crossing the main direction of the lamellae at an angle of about $64^{\circ}$. These lamellae were without exeption so thin and so rare that not all the optic determinations could be carried out.

\section{Chemistry}

As shown in the summary by Cerný (1972), the composition of natural and synthetic eucryptite (the ideal composition $\mathrm{LiAlSiO}_{4}$ ) varies widely. Mrose (1953) and Buerger (1954) considered eucryptite as a derivative from $\mathrm{SiO}_{2}$ (or $\mathrm{Si}_{12} \mathrm{O}_{24}$ ) and wrote the general formula:

$\left(\mathrm{Si}_{12-\mathrm{x}} \mathrm{Al}_{\mathrm{x}}\right)\left(\mathrm{Li}_{\mathrm{x}-\mathrm{y}} \mathrm{Al} \mathrm{y}_{\mathrm{y} / 3}\right) \mathrm{O}_{24}$

According to Mrose (1953) this formula indicates a complicated mechanism where $3 \mathrm{Li}+\mathrm{Al}$, insted of $\mathrm{Li}$ alone, provides valence compensation for the substitution of $\mathrm{Al}$ for $\mathrm{Si}$.
The Haapaluoma eucryptite was analysed by wet chemical methods on material separated from a bulk sample by means of heavy liquids. As was demonstrated by the X-ray powder diffraction pattern, the eucryptite fraction thus obtained did not contain notable amounts of impurities.

Table 2 shows the chemical analysis of the Haapaluoma eucryptite and the content of the unit cell on the basis of 24 oxygens. Omitting the water shown by the chemical analysis the formula of the mineral may be written:

$\mathrm{Li}_{4.94} \mathrm{Na}_{0.06} \mathrm{~K}_{0.03} \mathrm{Ca}_{0.04} \mathrm{Fe}_{0.09} \mathrm{Al}_{5.48} \mathrm{Si}_{6.54} \mathrm{O}_{24}$.

The separation of quartz from eucryptite is, however, very difficult or quite impossible, because the specific gravity and magnetic properties of both minerals are similar. Quartz replaces eucryptite in many of the samples studied and occurs as minute inclusions in the mineral (see Fig. 3). Therefore eucryptite was also analysed with an electron microprobe using oligoclase as a standard. The partial analysis showed: $\mathrm{SiO}_{2} 47.5$ wt $\%$ and $\mathrm{Al}_{2} \mathrm{O}_{3} 39.4 \mathrm{wt} \%$. If we accept the values of $\mathrm{SiO}_{2}$ and $\mathrm{Al}_{2} \mathrm{O}_{3}$ shown by the microprobe 
Fig. 3. Twinned eucryptite replaced by quartz (q, white) and cookeite (c, grey) veins. Photomicrograph, crossed nicols.

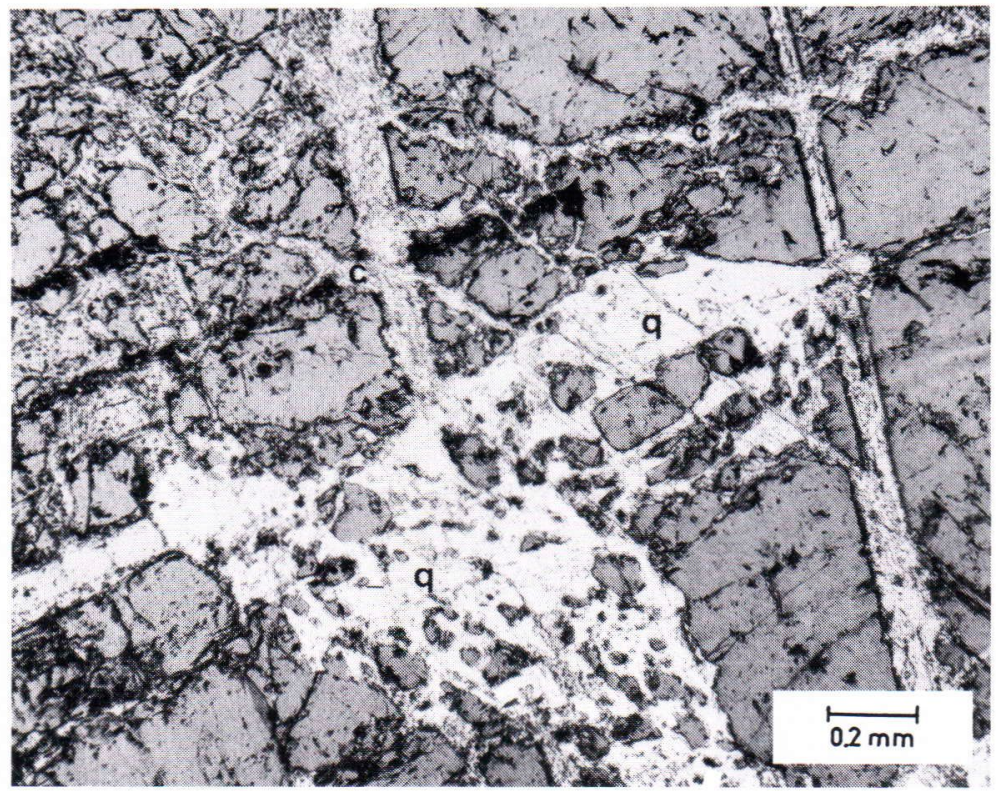

analysis and correct the chemical analysis, the formula of the Haapaluoma eucryptite may be written as follows (omitting the water and calculating on the basis of 24 oxygens): $\mathrm{Li}_{5.7} \mathrm{Na}_{0.1} \mathrm{Ca}_{0.1} \mathrm{Fe}_{0.1} \mathrm{Al}_{5.9} \mathrm{Si}_{6.0} \mathrm{O}_{24.0}$.

This result compares favourably with the composition of eucryptite calculated from the formula $\mathrm{LiAlSiO}_{4}\left(\mathrm{SiO}_{2} 47.69 \%, \mathrm{Al}_{2} \mathrm{O}_{3}\right.$ $40.46 \%, \mathrm{Li}_{2} \mathrm{O} 11.85 \%$ ); the high silica content shown by the wet chemical analysis is primarily due to quartz contamination. As to the chemical composition of eucryptite in general, it may be argued that the high silica content often observed in natural eucryptites analysed earlier may be due to the contamina-

Table 2. The chemical composition of the Haapaluoma eucryptite.

\begin{tabular}{|c|c|c|c|c|c|c|c|}
\hline & 1 & \multicolumn{2}{|c|}{2} & \multicolumn{2}{|c|}{3} & \multicolumn{2}{|l|}{4} \\
\hline $\mathrm{SiO}_{2}$ & 51.74 & $\mathrm{Fe}$ & 6900 & $\mathrm{Si}$ & 6.54 & $\mathrm{SiO}_{2}$ & 47.5 \\
\hline $\mathrm{Al}_{2} \mathrm{O}_{3}$ & 36.76 & $\mathrm{Mn}$ & 190 & $\mathrm{Al}$ & 5.48 & $\mathrm{Al}_{2} \mathrm{O}_{3}$ & 39.4 \\
\hline $\mathrm{CaO}$ & 0.30 & $\mathrm{Cu}$ & 660 & $\mathrm{Fe}^{+3}$ & 0.09 & & \\
\hline $\mathrm{Na}_{2} \mathrm{O}$ & 0.26 & $\mathrm{Sn}$ & 290 & $\mathrm{Ca}$ & 0.04 & & \\
\hline $\mathrm{K}_{2} \mathrm{O}$ & 0.16 & $\mathrm{Ga}$ & 140 & $\mathrm{Na}$ & 0.06 & & \\
\hline $\mathrm{Li}_{2} \mathrm{O}$ & 9.70 & $\mathrm{Sr}$ & 80 & $\mathrm{~K}$ & 0.03 & & \\
\hline $\mathrm{H}_{2} \mathrm{O}+$ & 1.02 & $\mathrm{Zr}$ & 60 & $\mathrm{Li}$ & 4.94 & & \\
\hline $\mathrm{H}_{2} \mathrm{O}-$ & 0.12 & $\mathrm{Cr}$ & 23 & $\mathrm{O}$ & 24.00 & & \\
\hline Tot. & 100.06 & $\mathrm{Be}$ & 23 & & & & \\
\hline
\end{tabular}

1. A wet chemical analysis (wt\%) by Prof. O. von Knorring.

2. The minor elements ( $\mathrm{ppm}$ ) Spectrochemical analysis by Miss Ringa Danielsson.

3. The unit cell content of the Haapaluoma eucryptite on the basis of 24 oxygens (after omitting the content of $\mathrm{H}_{2} \mathrm{O}$ and recalculating the sum of analysis to 100).

4. Partial electron microprobe analysis (wt\%) by Mrs. Tuula Hautala. 
tion of quartz or, to some extent, of other minerals.

The relatively high concentration of water and iron in the mineral studied is remarkable in comparison with other eucryptite analyses. The contents of minor elements (see Table 2) have not previously been reported in the litterature.

\section{X-ray crystallography}

The eucryptite was studied using X-ray single crystal and powder methods. a- and c-axis 0 - and 1-level precession photographs confirmed the trigonal symmetry of the mineral with the space group $R \overline{3}$. The lattice dimensions given in Table 1 were computed from powder diffraction data with the aid of unpublished least-square programs written by one of us (P.K.). The X-ray powder diffraction data compared with the d-values of the eucryptite from Bikita, Zimbabwe (see JCPDS-card 14-657) are given in Table 3 . Most of the weaker reflections ( $\leq 2 \%$ ) observed in the X-ray film of the Bikita eucryptite were also found in the DebyeScherrer camera films of the Haapaluoma eucryptite.

Slow diffractometer runs on a few samples showed single broad or double peaks. The doubling of peaks was clearly seen in the 303 and 410 reflections. The precession photographs of one single crystal, however, did not show any deviations from the trigonal symmetry, and the double peaks may be due to the compositional variation of the eucryptite nodules and crystals.

\section{Discussion}

Eucryptite is one of the rarer lithiumaluminium silicates in lithium pegmatites. An exeption is the Bikita pegmatite in Zimbabwe, in which eucryptite is an important lithium mineral occuring in thousands of tons. The mineral has been described from four localities in the United States (Brush and Dana 1880, Mrose 1953, Leavens 1968), from Bikita and some other localities in Zimbabwe (Hurlbut 1962, Grubb 1973), from the Tanco pegmatite in Canada (Černý 1972) and from Kola Penisula in U.S.S.R. (Sosedko and Gordienko 1957). Eucryptite occurs as crystals, irregular nodules or aggregates as in the Haapaluoma pegmatite or intergrown with albite. According to the descriptions, the mineral is closely associated with petalite or spodumene, or both.

Eucryptite has been synthetized in many experiments, and its stability field in the system $\mathrm{Li}_{2} \mathrm{O}-\mathrm{Al}_{2} \mathrm{O}_{3}-\mathrm{SiO}_{2}-\mathrm{H}_{2} \mathrm{O}$ has been studied by a number of authors (Roy et al. 1950, Stewart 1960, 1978 and Grubb 1973). These experiments and the mineral parageneses of eucryptite suggest that the subsolidus leaching of $\mathrm{SiO}_{2}$ from the lithium aluminosilicates formed earlier, spodumene $\left(\mathrm{LiAlSi}_{2} \mathrm{O}_{6}\right)$ or petalite $\left(\mathrm{LiAlSi}{ }_{4} \mathrm{O}_{10}\right)$, provides a mechanism by which eucryptite can form in pegmatites (Stewart 1960, 1978).

In the Haapaluoma pegmatite the mineral association cleavelandite-elbaite-lepidolite -spodumene-eucryptite-cookeite indicates that eucryptite is one of the late-stage crystallization products of the dyke. The pegmatite is a typical zoned lithium pegmatite with a fine-grained aplitic border zone, a coarser wall zone and a very coarse-grained intermediate zone with a number of quartz cores. After the crystallization of the bulk of the dyke the pegmatite was replaced by postmagmatic $\mathrm{Na}$ - and Li-rich fluids, filling fractures and cavities and brecciating the whole pegmatite. Haapala (1966) has divided the crystallization of the replacement bodies and fracture fillings of the pegmatite into two stages: the Na stage and the Li stage. Cleavelandite, quartz and schorl characterize the $\mathrm{Na}$ stage assemblage, whereas cleavelandite, 
Table 3. Comparison between the X-ray powder diffraction data of: 1. Eucryptite, Bikita, Zimbabwe (Rhodesia). Guinier camera, diameter $114.6 \mathrm{~mm}$ (see JCPDS-card 14-657). 2. Eucryptite, Haapaluoma, Finland. Diffractometer, $\mathrm{Ni}$-filtered $\mathrm{Cu}$-radiation $(\lambda \mathrm{CuK} \alpha=1.54178 \AA)$. The reflections marked with asterisks were used in computing unit cell parameters.

\begin{tabular}{|c|c|c|c|c|c|}
\hline \multirow[b]{2}{*}{$\mathrm{hkl}$} & \multicolumn{2}{|c|}{1.} & \multicolumn{2}{|c|}{2.} & \multirow[b]{2}{*}{ I } \\
\hline & d meas. & I & d meas. & d calc. & \\
\hline 101 & 7.13 & $<1$ & & & \\
\hline $110^{*}$ & 6.74 & 55 & 6.74 & 6.74 & 59 \\
\hline 021 & 4.897 & $<1$ & & & \\
\hline $012^{*}$ & 4.199 & 30 & 4.20 & 4.20 & 31 \\
\hline $211^{*}$ & 3.961 & 100 & 3.962 & 3.960 & 100 \\
\hline $300^{*}$ & 3.890 & 35 & 3.888 & 3.888 & 32 \\
\hline 202 & 3.566 & 6 & 3.566 & 3.563 & 20 \\
\hline $220^{*}$ & 3.369 & 95 & 3.368 & 3.368 & 97 \\
\hline $122^{*}$ & 3.151 & 14 & 3.149 & 3.150 & 35 \\
\hline $131^{*}$ & 3.046 & 10 & 3.045 & 3.045 & 25 \\
\hline 401 & 2.776 & $<1$ & & & \\
\hline $113^{*}$ & 2.740 & 80 & 2.741 & 2.740 & 74 \\
\hline $410^{*}$ & 2.546 & 60 & 2.547 & 2.546 & 72 \\
\hline 042 & 2.447 & 2 & 2.449 & 2.448 & 4 \\
\hline $303^{*}$ & 2.376 & 25 & 2.374 & 2.375 & 48 \\
\hline 232 & 2.301 & $<1$ & & & \\
\hline 330 & 2.247 & 14 & 2.243 & 2.245 & 15 \\
\hline 223 & 2.242 & 2 & & 2.240 & \\
\hline $\begin{array}{l}104 \\
241\end{array}$ & $\begin{array}{l}2.208 \\
2.143\end{array}$ & $<1$ & 2143 & & 2 \\
\hline $\begin{array}{l}241 \\
024\end{array}$ & $\begin{array}{l}2.143 \\
2.100\end{array}$ & $\begin{array}{r}2 \\
<1\end{array}$ & & 2.142 & 2 \\
\hline 502 & 2.072 & 2 & & & \\
\hline 214 & 2.004 & $<1$ & & & \\
\hline 422 & 1.980 & $<1$ & & & \\
\hline $600(413)$ & 1.943 & 10 & 1.942 & $1.945(1.941)$ & 21 \\
\hline 152 & 1.900 & $<1$ & & & \\
\hline 431 & 1.877 & 6 & 1.875 & 1.876 & 13 \\
\hline 520 & 1.869 & 10 & 1.869 & 1.868 & 18 \\
\hline 134 & 1.848 & $<1$ & & & \\
\hline $333^{*}$ & 1.797 & 25 & 1.797 & 1.798 & 31 \\
\hline 404 & 1.782 & 2 & 1.782 & 1.782 & 6 \\
\hline 342 & 1.765 & $<1$ & & & \\
\hline 161 & 1.745 & $<1$ & & & \\
\hline 324 (205) & 1.722 & $<1$ & & & \\
\hline 125 & 1.667 & 4 & 11667 & 1.666 & 5 \\
\hline 701 (351) & 1.639 & 2 & 1.639 & $1.639(1.639)$ & 2 \\
\hline $603^{*}$ & 1.632 & 8 & 1.632 & 1.632 & 2 \\
\hline 054 & 1.620 & 2 & 1.620 & 1.620 & 1 \\
\hline 621 & 1.593 & 2 & & & \\
\hline $710^{*}$ & - & - & 1.546 & 1.545 & 8 \\
\hline $006^{*}$ & - & - & 1.500 & 1.500 & 8 \\
\hline
\end{tabular}

- not given

quartz, spodumene, lepidolite, red tourmaline, beryl, fluorapatite, spessartine and cassiterite are typical minerals in the Li-stage assemblage. Eucryptite occurs with other lithium minerals, but it crystallized after these from later postmagmatic fluids that had decomposed spodumene crystals formed earlier and were thus enriched in lithium. In his summary of eucryptite, Černý (1972) has shown that, because of the scarcity of 
data, the interrelations between chemical composition, unit cell dimensions and refractive indices of eucryptite are obscure. The influence of isomorphous substitution of $\mathrm{Si}$ by $\mathrm{Li}+\mathrm{Al}$ seems to be difficult to trace. The eucryptite specimens richest in silica give refractive indices and unit cell dimensions similar to those of samples poorer in silica. The optical properties in particular seem to be identical within the limits of measuring accuracy.

Most of the physical properties and the occurrence of the Haapaluoma eucryptite agree well with those reported in the literature. Similar polysynthetic twinning, however, has not been described before from eucryptite samples. The twinning may represent the transformation twinning observed in many minerals. Nevertheless, experimental studies show that the inversion temperature of high temperature $\beta$-eucryptite to low temperature $\alpha$-eucryptite is very high, viz. $848^{\circ} \mathrm{C}$, at atmospheric pressure (Isaacs and Roy 1958). The mineral paragenesis show that the Haapaluoma eucryptite crystallized in postmagmatic replacement bodies and fracture fillings much below this temperature limit (cf. Haapala 1966, 64-65, Lahti 1981, 71-76).

Pinkish fluorescence is characteristic of all known synthetic and natural eucryptite specimens exluding the Haapaluoma eucryptite. As reported by Černý (1972), the fluorescence of the Tanco eucryptite fades rapidly after the larger grains have been crushed and disappears completely in powdered material. Thin sections show that the Haapaluoma eucryptite is highly fractured (cf. Fig. 3). This observation confirms the authors in their opinion, that mechanical deformation together with partial alteration have inhibited the fluorescene of the mineral.

Acknowledgements. The authors are indebted to Mr. Heikki Koivisto and Mr. Pekka Paananen for the mineral specimens, to Miss Ringa Danielsson for the spectrochemical analyses to Mrs. Tuula Hautala for the electron microprobe determinations, to Mrs. Mirja Saarinen for helping with the $\mathrm{X}$-ray studies and to Mr. Erkki Halme for taking the photographs.

\section{References}

Buerger, M. J., 1954. The stuffed derivatives of the silica structures. Am. Mineral. 39, 600-614.

Brush, G. J. \& Dana, E. S., 1880. On the mineral locality at Branchville, Connecticut. Am. J. Sci. 20, 257-285.

Cerný, P., 1972. The Tanco pegmatite at Bernic Lake, Manitoba. VII. Eucryptite. Can. Mineral. 11, 708-713.

Grubb, P. L. C., 1973. Paragenesis of spodumene and other lithium minerals in some Rhodesian pegmatites. Spec. Publ. Geol. Soc. S. Afr. 3, $201-216$.

Haapala, Ilmari, 1966. On the granitic pegmatites in the Peräseinäjoki-Alavus area, South Pohjanmaa, Finland. Bull. Comm, géol. Finlande 224. 98 p.
Haapala, Ilmari; Sivvola, Jaakko \& Löfgren, Arvo, 1967. On the Haapaluoma Sc-bearing columbite and its inclusions. Bull. Comm. géol. Finlande 229, 95-100.

Hurlbut, Cornelius S., Jr., 1962. Eucryptite from Bikita, southern Rhodesia. Am. Mineral 47, $557-561$.

Isaacs, Thelma \& Roy, Rystym, 1958. The $\alpha-\beta$ inversions in eucryptite and spodumene. Geochim. Cosmochim. Acta 15, 213-217.

Lahti, Seppo I., 1981. On the granitic pegmatites of the Eräjärvi area in Orivesi, southern Finland. Geol. Surv. Finland, Bull. 314, 82 p.

Leavens, Peter B., 1968. Eucryptite and Bikitaite from King's mountain, North Carolina. Am. Mineral, 53, 1202-1207.

Mrose, Mary E., 1953 a-eucryptite problem. Am. Mineral. 38, 353. 
Roy, Rustum; Roy, Della M. \& Osborn, E. F., 1950. Compositional and stability relationships among the lithium aluminosilicates: eucryptite, spodumene and petalite. J. Am. Cer. Soc. 33, $152-159$.

Sosedko, A. F. \& Gordienko, V. V., 1957. Ehvkriptit iz pegmatita severnoj chasti kol'skogo poluostrova. Dokl. Adad. Nauk. SSSR, Geol. 116, 1, 135-136 (in Russian).

Stewart, David B., 1960. The system $\mathrm{LiAlSiO}_{4}-$ $\mathrm{NaAlSi}_{3} \mathrm{O}_{8}-\mathrm{H}_{2} \mathrm{O}$ at 2000 bars. Int. Geol. Congr.
XXI Sess. Norden 1960. Part XVII, Minerals and Genesis of Pegmatites, 15-30.

Stewart, David B., 1978. Petrogenesis of lithiumrich pegmatites. Am. Mineral. 63, 970-980.

Tyrväinen, Aimo, 1970. Kallioperäkartta (PreQuaternary rocks), lehti-sheeet-2223 Alavus. Suomen geologinen kartta (Geological map of Finland) $1: 100000$.

Manuscript received, November 10, 1981 